\title{
IAMJ
}

INTERNATIONAL

AYURVEDIC

MEDICAL JOURNAL

ISSN: 2320-5091

Impact Factor: 6.719

\section{EFFECTS OF UTTARA BASTI, IN THE MANAGEMENT OF KLAIBYA W.S.R. ERECTILE DYSFUNCTION - A CONCEPTUAL REVIEW}

\author{
Mukesh Kumar Sagar ${ }^{1}$, Umesh Shukla ${ }^{2}$, Babita Dash ${ }^{3}$ \\ ${ }^{1}$ PG Scholar, ${ }^{2}$ Professor, Head \& Guide, ${ }^{3}$ Lecturer \& Co-Guide \\ PG Department of Panchakarma, Pt. Khushilal Sharma Government (Autonomous) Ayurveda College \& Institute, \\ Bhopal, Madhya Pradesh, India
}

Corresponding Author: drmukeshkumarsagar@gmail.com

\section{https://doi.org/10.46607/iamj2008122020}

(Published online: December 2020)

Open Access

(C) International Ayurvedic Medical Journal, India 2020

Article Received: 09/11/2020 - Peer Reviewed: 14/11/2020 - Accepted for Publication: 18/11/2020

(D) Check for updates

\begin{abstract}
Ayurveda is a science of life which believes in treating body, mind and soul for ensuring a complete state of health. Sexuality has fascinated the people in all walks of life from ancient time to present. The male sexual dysfunction includes all nature of disturbances of coital performance and sexual congress in male. This condition has been decoratively described as "Klaibya" in Ayurvedic classics and "Erectile Dysfunction" in modern texts. On the basis of the cause, six types of Klaibya are mentioned by Acharya Sushruta and four types of Klaibya are mentioned by Acharya Charaka in Ayurvedic classics. On the basis of the cause, two types of Erectile Dysfunctions are mentioned in modern medical science. The disease Klaibya is a multifactorial ailment, mainly including Bahu Doshavastha as a whole and Shukrakshaya in definite, Mano Dosha, and Shukravaha Sroto Dusti. The Basti administered through the Uttara Marga (Mutra and Shukra Marga in male) and having the Sreshtha Guna (superior qualities) is known as Uttara Basti. Uttara Basti is one among the Panchakarma is capable of performing all sorts of actions like Shodhana, Samana and Bramhana etc. By virtue of the specific type and drugs utilised it effectively overcomes the aggravated Vata. It specially ameliorates the Bahu Dosavastha due to its Shodhana action.
\end{abstract}

Keywords: Shukrakshaya, Sukravaha Sroto Dusti, Uttara Basti, Mansik Klaibya, Shodhana, Samana and Bramhana 


\section{INTRODUCTION}

Healthy sexual functioning plays pivotal role in maintaining the hormones and happiness in marital life. The absence of which hampers the marital affiliation leaving to frustration sometime ends into dissociate and causes incompetence in performing the routine duties. The male sexual dysfunction includes all nature of disturbances of coital performance and sexual congress in male. This condition has been decoratively described as "Klaibya" in Ayurvedic classics and "Erectile Dysfunction" in modern texts. Erectile Dysfunction is a sexual problem in males because of which erection cannot be maintained or the erection is not firm enough for sexual intercourse. ED is characterized by the regular or repeated inability to achieve or maintain an erection of satisfactory rigidity to finish sexual activity. It is defined as the "persistent or recurrent inability to achieve and maintain a penile erection of sufficient rigidity to permit satisfactory sexual activity for at least 3 months" ${ }^{[1]}$. ED often has an impact on the emotional well-being of both men and their partners. Many men do not seek treatment due to feelings of embarrassment. About $75 \%$ of diagnosed cases of ED go untreated ${ }^{[2]}$. Erectile dysfunction (ED) is a common medical condition that affects approximately 100 million men worldwide and is currently recognized as a major public health problem. It is estimated that nearly one-half of men older than 40 years have some degree of ED. While in 1995, ED affected over 152 million men worldwide, it is projected that by 2025 , more than 320 million patients will be afflicted with the largest projected increases in the developing world ${ }^{[3-4]}$. The overall prevalence of ED has been reported to be $16-25$ per cent in the general population depending on the cohort of study and the definition of ED being applied ${ }^{[5]}$.

Age is a strong determinant of occurrence of ED, and epidemiological studies indicate a strong relationship between ED and advancing age. While men aged 50-59 years have a 3.6 times higher risk of developing ED as compared to those aged 18-29 years, the risk is even higher (6-7 times) among males older than 70 years ${ }^{[6]}$. Age-related hormonal, metabolic and inflammatory as well as increased prevalence of other risk factors for ED in the older population may be responsible for this association. When ED occurs in younger males, it is associated with a greater increase in the risk of future cardiac events as compared to its first detection in older males ${ }^{[7]}$. Therefore, younger men with early-onset ED may be the ideal candidates for intensive $\mathrm{CV}$ risk factor screening and medical interventions. Global incidence of Erectile Dysfunction (ED) is increasing day by day and it is a very common encounter problem in practice. Due to Erectile Dysfunction, infertility is common in male. No proper treatment except hormonal therapy which is full of side effects is available.

Disease Review: According to Ayurveda, ED is basically a condition of low vitality. Generally, vitiation of Vata Dosha is responsible for Klaibya or ED. On the basis of the cause, six types of Klaibya are mentioned by Acharya Sushruta in Ayurvedic texts, e.g. 1. Manasik Klaibya is caused by psychological factors, 2. Shukrakshayaj Klaibya is caused by deficiency of Shukra Dhatu, 3. Ativyavay Klaibya is caused by excessive coitus, 4. Aghataj Klaibya is caused by surgical or accidental trauma, 5. Sahaj Klaibya means congenital and 6. Shukra Nirodhaj Klaibya is caused by suppression of sexual urge ${ }^{[8]}$. On the basis of the cause, four types of Klaibya are mentioned by Acharya Charaka in Ayurvedic texts, e.g. 1. Bijopghataj Klaibya is caused by loss of Shukra Dhatu. 2. Dhvajbhanga Klaibya is caused by surgical or accidental trauma, 3. Jarajanya Klaibya caused by old age and 4. Shukrakshayaj Klaibya is caused by deficiency of Shukra Dhatu ${ }^{[9]}$. This disease is a multifactorial condition, mainly involving Bahu Dosavastha as a whole and Sukrakshaya in specific Mano Dosha and Sukravaha Shroto Dushti. 


\section{SAMPRAPTI:}
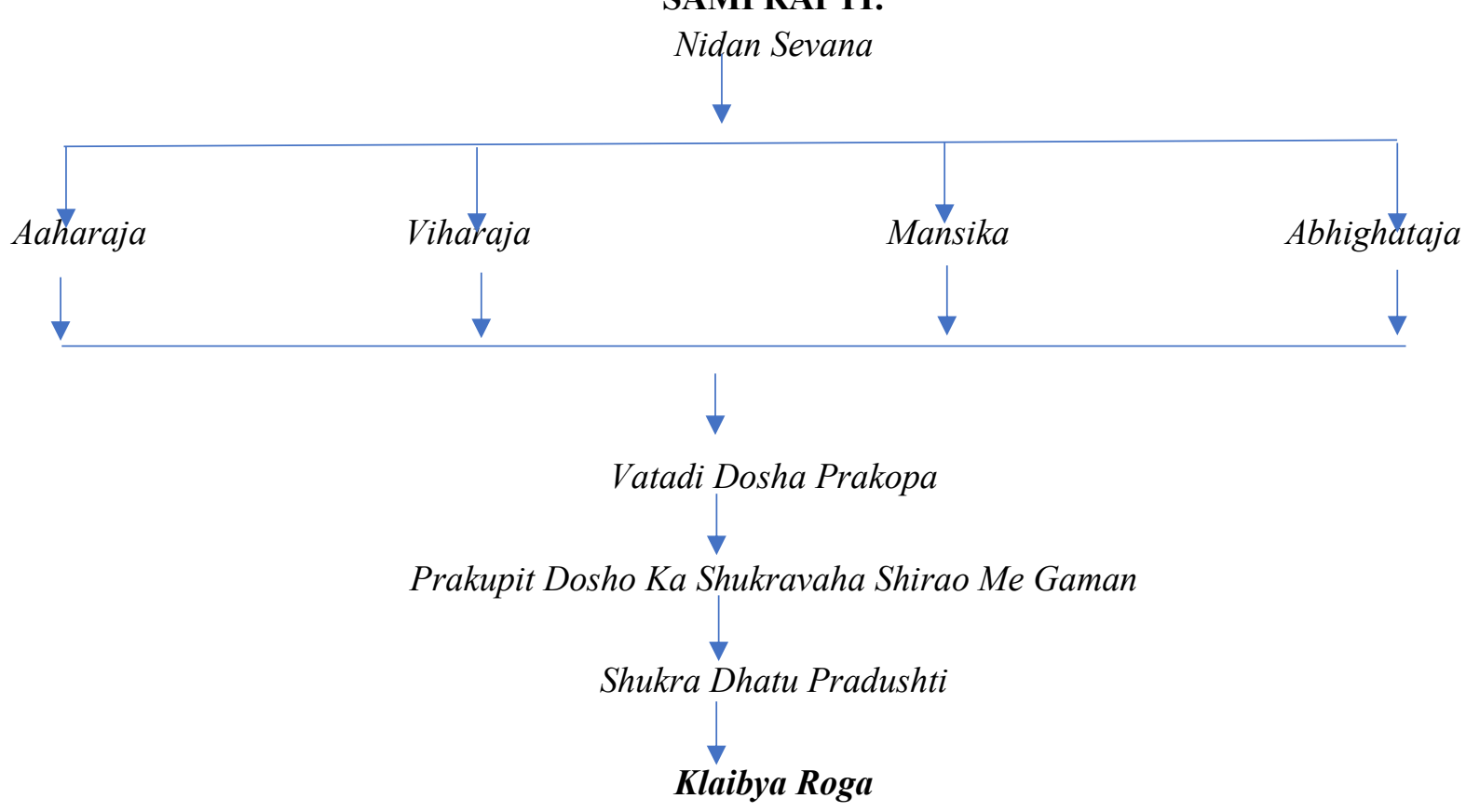

MANAGEMENT: Uttara Basti (a type of Basti) one among the Panchakarma is capable of performing all sorts of actions like Shodhana, Samana and Bramhana etc. by virtue of the specific type and drugs utilized in it and effectively overcomes the aggravated Vata. Uttara Basti the best among the variations of Basti (en- ema), is specified in the management of several Urological, Andrological and Gynaecological conditions. It is a technique by which medicaments are introduced into intra vesicle, intra vaginal and intra uterine route, by particular techniques to achieve desired therapeutic outcome. In males, this procedure is administered intravesical and intra-urethral.

Table 1: Various Sneha Used in Uttara Basti in Different Conditions:

\begin{tabular}{|l|l|l|}
\hline S. No. & Conditions & Sneha \\
\hline 1. & Asthenospermia & Pippalyadi Taila / Mahamasha Taila \\
\hline 2. & Azoospermia $^{[10]}$ & Pippalyadi Taila / Anu Taila / Ksheerabala Taila \\
\hline 3. & Erectile Dysfunction $^{[11,12 \& 13]}$ & Ashwagandha Taila / Sahacharadi Taila / Arjuna Shalmali Sidda Taila \\
\hline 4. & Oligospermia $\left.^{[14} \& 15\right]$ & Ashwagandha Taila / Tila Taila / Mahamasha Taila \\
\hline 5. & Premature ejaculation $^{[16]}$ & Ashwagandha Ghrita / Sahacharadi Taila \\
\hline
\end{tabular}

Material and Methods: Literary resources like classical textbooks of Ayurveda, clinical trials, published manuscripts and clinical experience of treating cases.

Equipment's required: Surgical gloves, Sponge holding forceps, Cotton swabs, Savlon, Betadine or Triphala Kashaya, Green wound cloth with a central hole, Glass / Steel bowl of 50ml capacity, Infant feeding tube no. 8 or Disposable rubber catheter No 6/7 or according to the size of Urethral meatus, Kidney tray,
Disposable syringe of $50 \mathrm{ml}$ capacity, Medicine: $M a$ hamasha Taila (oil)

Precautions / Safety measures: All instruments including Sneha (Ghee / oil) medicine should be autoclaved to avoid UTI., The medicine is checked for Luke warm temperature before administration., The catheter should not be forcefully inserted in case any obstruction is met., Retention time ranges between three to six hours. 
PROCEDURE: Before main procedure, two sitting of Asthapan Basti with Triphala Kwatha should administered for Koshtha Shuddhi. Abhyanga Karma and Svedana Karma should be done preferably over the back, groin and abdomen, then Yavagu added with Ghee should be given for drinking. ${ }^{[17]}$ The patient should be brought to Basti room and advised to sit on the stool having the height equal to the knee of patient. The penis is made to erect. Then the Basti Yantra holding the
Kwatha or Sneha is taken and the Basti Netra along with the Mutra Marga is greased with Sneha. Netra is carefully introduced into the Mutra Marga and Basti Putaka is compressed uniformly. After Shodhana, one day rest, then Uttara Basti with Mahamasha Taila- 24 $\mathrm{ml}$ oil will be instilled into the bladder by using sterile urethral catheter under aseptic precautions on $1^{\text {st }}$ three sitting every day, then 3 days gape and after $2^{\text {nd }}$ three sitting every day for 6 sitting.

Table 2: Treatment Regimen:

\begin{tabular}{|c|c|c|c|c|}
\hline Procedure & Duration & Drugs & Dose & Time \\
\hline $\begin{array}{l}\text { Asthapan Basti (Koshtha } \\
\text { Shodhnarth) }{ }^{[18]}\end{array}$ & Two Sitting & $\begin{array}{l}\text { Shodhana } \\
\text { Dravya }{ }^{[19]}\end{array}$ & $\begin{array}{l}\text { Dvadasha Prasritika } \\
{ }^{[20]}(1152 \mathrm{ml})\end{array}$ & $\begin{array}{l}\text { Before } \\
\text { Meal }\end{array}$ \\
\hline Uttara Basti & $\begin{array}{l}\text { Six Sitting; } 1^{\text {st }} \text { three sitting Every day, then } \\
\text { three days gape and after } 2^{\text {nd }} \text { three sitting } \\
\text { every day }{ }^{[21]} \text {. }\end{array}$ & $\begin{array}{l}\text { Mahamasha } \\
\text { Taila }^{[22]}\end{array}$ & Ardha Pal ${ }^{[23]}(24 \mathrm{ml})$ & $\begin{array}{l}\text { After } \\
\text { meal }\end{array}$ \\
\hline
\end{tabular}

Mode of Action of Uttara Basti: Uttara Basti (a type of Basti) one among the Panchakarma is capable of performing all sorts of actions like Shodhana, Samana and Bramhana etc. In Klaibya Roga mainly involvement of Vata Dosha. Taila (oil) is the best medicine of Vata Dosha for Samana. In this procedure we take Mahamansha Taila (oil). Mahamansha Taila is best for Bramhana Karma. The lower part of the body is administered by a subtype of Vata called as Apana Vayu. This Vayu or Vata helps in controlling and governing all the activities taking place in the lower part of the body. Its centres of control are colon, pelvis, urinary bladder and lower limbs. If the Apana Vayu is at its efficient best and it did not vitiate all the events related to the abovementioned organs take place easily and naturally. But if the Vata gets vitiated or moves in reverse direction i.e. upward direction (generally Apana Vata tends to move in downward direction, expelling and excreting things being its primary function) or gets obstructed functionally by other subtypes of Vayu or Pitta or Kapha (Avarana) or gets weak in function, the functions related to the above mentioned organs and parts of the body will be disturbed. Hence, the medicines administered through urethral route helps to balance primary- Apana Vata and its associated other sub Doshas, thereby leading to cure or relief from the respective disorders. The Uttara Basti has a cleaning action especially Niruha Basti. By purgative action of Uttara Basti in the urinary bladder and other genital passages, the process of urination and sexual functions will be re-established. The organs will be clean and sterile and will get rid of swelling, irritation, inactivity and contaminations. The Sneha Basti administered in Uttara Basti will be having a helpful role. They are nutritive in function and will improve the blood passage, nerve conduction and immunity of the organs.

Table 3: Recommendations of Various Conditions with Various Sneha For Further Scope In Uttara Basti Research Trial:

\begin{tabular}{|l|l|l|}
\hline S. No. & Conditions & Sneha \\
\hline 1. & Anti-sperm antibodies & Dashamula Taila / Balaguduchyadi Taila \\
\hline 2. & Burning ejaculation & Chandanadi Taila \\
\hline 3. & Dysuria & Brihatyadi Kashaya / Panchavalkala Kashaya / Mutra Virajaniya Gana Kashaya \\
\hline 4. & Epididymitis & Dhanwantara Taila / Mahanarayana Taila \\
\hline 5. & Genitalia pain & Mahanarayana Taila /Shatawhadi Taila \\
\hline
\end{tabular}


Mukesh Kumar Sagar et al: Effects Of Vttara Basti, In The Management Of Klaibya W.S.R. Erectile Dysfunction -

A Conceptual Review

\begin{tabular}{|l|l|l|}
\hline 6. & Maturation arrest & Shatapaki Bala Balashwagandha Taila \\
\hline 7. & OAT Syndrome & Ksheerabala Taila / Balaguduchyadi Taila \\
\hline 8. & Pyobacterospermia & Shukra Shodhana Gana Kashaya / Chandana-Sariva Sidda Kseera \\
\hline 9. & Teratozoospermia & Phala Ghrita / Dashamula Taila \\
\hline 10. & Varicocele & Amrutadya Taila / Sahacharadi taila 21 / Yashtimadhu Taila \\
\hline
\end{tabular}

Contra Indications: Diabetes mellitus, Anatomical urethral stricture, Hypersensitivity, Carcinoma of penis, Hypo/Epispadias, Phimosis

\section{DISCUSSION}

Before starting Uttara Basti, Niruha Basti (decoction enema) should be given for two days, to obtain Marga Shuddhi (purification of channels) and Ashaya Prashithila. Prior to the management of Uttara Basti, Sthanika Abyanga (local oleation therapy) followed by Mridu Nadi Sweda (mild sudation therapy) may help in pacifying Vata Dosha and also surge the drug absorption by smooth muscles. When applied with proper indications Uttara Basti plays a significant role in the disorders of Klaibya and shows amazing results, strict aseptic safety measures and dangerous carefulness. On the basis of above study, it is concluded that Uttara Basti is a very useful local treatment and off- course used in the management of Klaibya for the fruitful outcomes.

\section{CONCLUSION}

Although very precisely mentioned in the classics, the male Uttara Basti is limited to a handful of practitioners. Main property of Mahamansha Taila is Samana and Bramhana. This approach of Ayurvedic medicinal procedure has wide applicability and has been scientifically proved to be best route of administering the drug locally on target organs of uro-genital system to achieve best possible results. Thus, the recommendations provided through this paper have been customized based on several successful trials. This evidence-based practice of Male Uttara Basti procedure shall prove more beneficial for the upcoming clinicians and will help in its exploration to the entire scientific world.

\section{REFERENCES}

1. Chowdhury SH, Cozma AI, Chowdhury JH. Erectile Dysfunction. Essentials for the Canadian Medical Licensing Exam: Review and Prep for MCCQE Part I. 2nd edition. Wolters Kluwer. Hong Kong. 2017.
2. Frederick, LR; Cakir, OO; Arora, H; Helfand, BT; McVary, KT (October 2018). "Undertreatment of Erectile Dysfunction: Claims Analysis of 6.2 Million Patients". The Journal of Sexual Medicine. 11 (10): 2546-53. doi:10.1111/jsm.12647. PMID 25059314.

3. Ayta IA, McKinlay JB, Krane RJ. The likely worldwide increase in erectile dysfunction between 1995 and 2025 and some possible policy consequences. BJU Int 1999; 84: 50-6.

4. McKinlay JB. The worldwide prevalence and epidemiology of erectile dysfunction. Int J Impot Res 2000; 12 (Suppl 4): S6-11.

5. Rosen RC, Fisher WA, Eardley I, Niederberger C, Nadel A, Sand M; Men's Attitudes to Life Events and Sexuality (MALES) Study. The multinational Men's Attitudes to Life Events and Sexuality (MALES) study: I. Prevalence of erectile dysfunction and related health concerns in the general population. Curr Med Res Opin 2004; 20: 607-17.

6. Feldman HA, Goldstein I, Hatzichristou DG, Krane RJ, McKinlay JB. Impotence and its medical and psychosocial correlates: results of the Massachusetts male aging study. J Urol 1994; 151: 54-61.

7. Inman BA, Sauver JL, Jacobson DJ, McGree ME, Nehra A, Lieber MM, et al. A population-based, longitudinal study of erectile dysfunction and future coronary artery disease. Mayo Clin Proc 2009; 84: 108 13.

8. Kaviraj Dr. Ambikadatt Shashtri. Sushruta Smhita. Su.1, Part 1. Chikitsa Sthan. Varanasi: Chaukhambha Sanskrit; Edition 2014. P.147-148.

9. Pt. Kashinath Shashtri, Dr. Gorakhnath Chaturvedi. Charaka Samhita. Ch.1 Part 2. Varanasi: Chaukhambha Vishvabharati; Edition 2012. P.863-867.

10. Sharma MH and Singh G, Standardization of Uttarabasti and its role in the Management of shukra- dusti with reference to Obstructive azoospermia. DPC Dissertation, Gujarat Ayurveda University, Jamnagar, 1997.

11. Banothe $\mathrm{G}$ et al. Efficacy of Ayurveda Formulations 
and Basti Chikitsa on Mutraghata w.s.r. to Benign Prostatic Hyperplasia, Int. J. Ayur. Pharma Research, 2014; 2(7): 5-11.

12. Nandigoudar SN, A Comparative Clinical Study To Evaluate The Effect Of Uttara Basti And Matra Basti In Klaibya With Special Reference To Erectile Dysfunction, RGUHS 20, Pg 84-86.

13. Pareek T, Role of Panchakarma Chikitsa in the Management of Klaibya: A Case Study, AYUSHDHARA| September - October 2016 | Vol 3 | Issue 5, Pg 884887.

14. Arun H M, Role of Uttara Basti in the management of Klaibya (Erectile dysfunction); RGUHS 2001.

15. Bhosale PN, Management of Ksheen Shukra (Oligoasthenospermia) With Uttara Basti, RGUHS 2009, Pg 75-76.

16. Jithesh, Uttarabasti in the management of oligospermia. MD Dissertation, Govt. Ayurvedic College. Thiruvananthapuram Kerala University, 2003.

17. Dr. Brahmanand Tripathi. Astang Hrdayam. Sutra Sthan. Delhi: Chaukhamba Sanskrit Pratishthan; Edition 2019. P.240.

18. Dr Brahmanand Tripathi. Astang Hrdayam. Sutra Sthan. Delhi: Chaukhamba Sanskrit Pratishthan; Edition 2019. P.240.

19. Kaviraj Dr. Ambikadatt Shashtri. Sushruta Smhita. Su.1, Part 1. Chikitsa Sthan. Varanasi: Chaukhambha Sanskrit; Edition 2014. P.214.

20. Pt. Kashinath Shashtri, Dr. Gorakhnath Chaturvedi. Charaka Samhita. Ch.1 Part 2. Varanasi: Chaukhambha Vishvabharati; Edition 2012. P.997.

21. Pt. Kashinath Shashtri, Dr. Gorakhnath Chaturvedi. Charaka Samhita. Ch.1 Part 2. Varanasi: Chaukhambha Vishvabharati; Edition 2012. P.1066.

22. Pt. Saryu Prasad Tripathi. Bhaishajyaratnawali. Lucknow: Rajkumar Press; Edition 1957. P.466.

23. Pt. Kashinath Shashtri, Dr. Gorakhnath Chaturvedi. Charaka Samhita. Ch.1 Part 2. Varanasi: Chaukhambha Vishvabharati; Edition 2012. P.1063-1064.

24. Dr. Swarda R Uppin. A Customized Practice of Male Uttara Basti: Clinical Insights. ISSN No. 2277 - 8179. Nov 2019.

\section{Source of Support: Nil Conflict of Interest: None Declared}

How to cite this URL: Mukesh Kumar Sagar et al: Effects Of Uttara Basti, In The Management Of Klaibya W.S.R. Erectile Dysfunction - A Conceptual Review. International Ayurvedic Medical Journal \{online\} 2020 \{cited December, $2020\}$ Available from: http://www.iamj.in/posts/images/upload/5327 5332.pdf 